MORDENITE DEPOSITS AND ZEOLITE ZONATION IN THE

HORN MOUNTAINS AREA, SOUTH-CENTRAL ALASKA

By

D. B. Hawkins

SPECIAL REPORT 9

Occurrence of mordenite, heulandite, and laumontite formed by burial metamorphism of marine vitric tuffs. The extensive mordenite deposits may have economic importance.

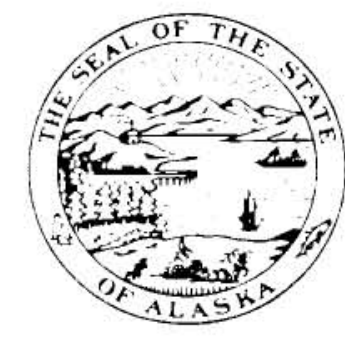




\section{STATE OF ALASKA}

Jay S. Hammond, Governor

(iuy R. Martin, Commissioner, Depl. of Nulural Resources

Ross G. Schaff, State Geologist

For sate by Alaska Division of (ieological and Geophysical Survevs, P.O. Box 80007, College, 99701:323 F. 4th Ave., Anchorage, 99501; P.(). Box 2.438, Ketehikan, 99901; and Pouch M, Juneau, 99811 - Price \$1.00. 


\section{CONTENTS}

\begin{tabular}{|c|c|c|c|}
\hline & Pinge & & Page \\
\hline Alostract. & 1 & 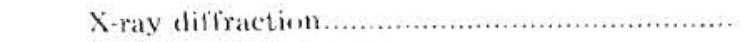 & 2 \\
\hline Introduction.... & 1 & Field test for zeolites....................................... & 3 \\
\hline 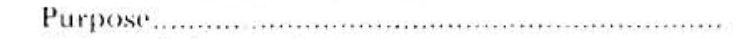 & 1 & 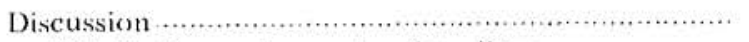 & 3 \\
\hline 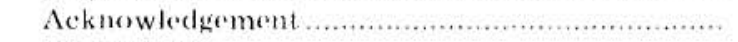 & 1 & Distribution and genesis of zeolites & \\
\hline 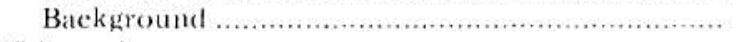 & 1 & in Alfred Creek-Albert Creek area................... & 3 \\
\hline 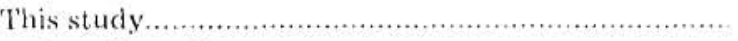 & 1 & 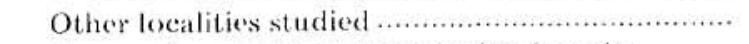 & 7 \\
\hline 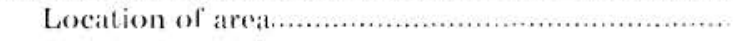 & 1 & Eeonomic potential of mordenite deposits........... & 7 \\
\hline 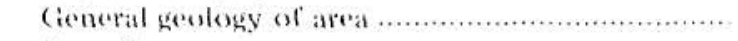 & 1 & 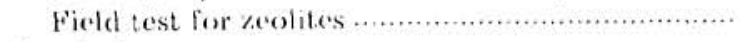 & 8 \\
\hline Samplings, & 2 & 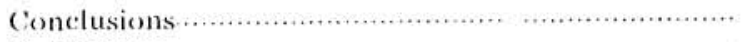 & 8 \\
\hline 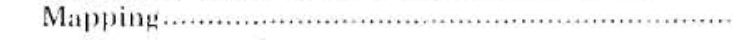 & 2 & References & 8 \\
\hline Laboratory studies... & 2 & & \\
\hline
\end{tabular}

\section{ILLUSTRATIONS}

PLATE 1. Map and sample localities of areat studied

2. Recommaissance geologie map) and sample localities of the Nibert (newek and
Alfod Croek areats
In pocket

It pocket

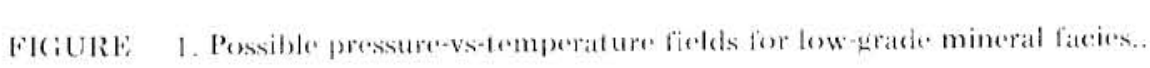

\section{TABLES}

TABLE 1. Sample number, hand-specimen description, and mineraloug as determined by $X-r a y$ ditliaction and results of field test ............................. 


\title{
MORDENITE DEPOSITS AND ZEOLITE ZONATION IN THE HORN MOUNTAINS AREA, SOUTH-CENTRAL ALASKA
}

\author{
By D. B, llawkins'
}

\begin{abstract}
ABSTRAC'T
Extensive mordenite-rich tulfs occurring with the Talkeetna formation in the Horn Mountains area of south-central Alaskat are of commercial grade. The properties of the mordenite with regard to commercial requirements need further study.

The zeolites in the area were formed by hurial diagenesis and regional metamorphism of lava and volcanic detritus deposited in a rugeosynclinal trough. Heulandite and laumontite zones suggest that the sediments were subjected to a maximum temperature near $200^{\circ} \mathrm{C}$ at water pressures from 0.5 to 3 kilobars, which corresponds to burial depths of 1 to 10 kilometers.

The occurrence of mordenite within the heulandite zone is probably due to the fine-grained nature of the parent tulfs, which caused a higher silicat activity than elsewhere in this zone, thereby producing mordenite.

Analcime, which occurs locally within the mordenite zone, may have been formed from mordenite or hea landite tuffs by the action of solutions that were more alkaline locally than elsewhere in the zone.

The field test by Culfaz and others (1973) gives re liable results and should lind use in zeolite prospecting.
\end{abstract}

\section{INTRODUCTION}

\section{PURP()SE}

'The primary purpose of this study was to investigate the mordenite deposits of the florn Mountains areat, upper Matanuska Valley, Alaska. A subordinate pur. pose was to prepare a reconnaissance greslogic map of the area showing the geologic setting of the mordenite deposits. A final purpose was to sample other areas in the vicinity of the study area in search of other reolite deposits. This study is a continuation of that reported previously (Hawkins, 1973).

\section{ACKNOWLEDGGMEN'}

I would like to thank D.C. Hartman, T.F.. Smith, and N.C. Veach of the Alaska State Division of (ieological and Geophysical Surveys for funding, logistical, and analytical support of this study. I also wish to thank my colleague, Donald (irybeck, for his assistance with photomicrography and his helpful discussions during the course of this work. Hy thanks are also extended to M.S. Robuson for preparation of thin sections. Finally, I wish to thank my sons, Mike and Bill Hawkins, who served as my field assistants.

\section{BACK(iROUNI)}

The zeolite minerals are of interest as important industrial minerals of use in a variety of fields. The mineralogical, chemical, and industrial properties of the zeolites were briefly deseribed by Hawkins (1973) and more recently in two detailed general review articles on the use and properties of zeolites: Mumpton (1973) and Munson and sheppard (1974). These articles should be consulted by these interested in an overview of the utility and economic value of zeolites.

\section{TIIIS STUDY}

\section{LOCATION OF AREA}

The area studied (pl. 1) is located about 12 miles north of 'T'ahneta Pass Lodge at mile 121 of the Glem Ilighway. The area is accessible by either off-the-road rehicles, via roads to nearby placer mines; or by floatequipped fixed-wing aircraft, which can land at South lake on the southern extremity of the study area.

\section{GENERAL, GEOLOGY OF AREA}

The study consisted of investigating the zeolitization of the lower Jurassic Talkeetna formation in the Horn Mountains. As shown by Grantz (1965), splay faults associated with the Caribou fault have isolated and exposed a triangular section of the Talkeetna formation in the Horn Mountains area.

The Talkeetna formation in this area consists mainly of thick units of pyroclastic sandstones, siltstone, and (laystone (coarse and fine water-laid tuffs); andesitic and basaltic lavas are also present (pl. 2). Although the formation is mostly marine, no marine fossils were found. Wood fragments and casts were observed in some units. The Talkeetna formation as a whole seems to be typical of a eugeosynclinal deposit. 


\section{SAMPLING}

The primary purpose of the study was to determine the extent and grade of the mordenite deposit in the area. To this end, fist-sized samples were collected from the numerous outcrops of tuffs, tuffaceous wackes, and lavas in the area. Plates 1 and 2 show the localities from which samples were collected.

\section{MAPPING}

Because general mapping was of secondary importance, the geologic map shown in plate 2 is incomplete. Salient features of the map are based on Grantz (1965)---particularly the contact between the Talkeetna formation and the Tuxedni formation, and the faults (either mapped or inferred); this report also contains details of Quaternary deposits not shown in plate 2. Mapping of the units within the Talkeetna formation was done as part of the study. The map units shown in plate 2 are based on hand-specimen properties and topographic expression of the units. Map unit Jtk-5, the easternmost unit, consists mainly of volcanic sandstone (with some tuffs), and basalt and andesite flows. The unit is moderately altered to clay minerals. Zeolitization is not pronounced, although void-fillings of heulandite are evident in the coarser sandstones. Unit Jtk-5 forms a series of low, northeasttrending ridges at the mouths of Albert and North Creeks.

Map unit Jtk-4 is characterized by pumiceous and vitric tuffs with subordinate tuffaceous wackes, basalt, and andesite flows. Zeolitization is more extensive than in unit Jtk-5, with heulandite void fillings and veinlets especially common in exposures of coarser lithologies in the upper parts of Albert and North Creeks. Unit Jtk-4 is a swale-forming unit; that is, it forms the low, rolling, gently sloping hills crossing the midsection of Albert Creek and is characterized by a thin-bedded, tanweathering tuff capping these hills.

Map unit Jtk-3 consists of pumiceous and vitric tuff's generally altered to mordenite. Local sections consist of mordenite-rich vitric tuffs. Unit Jtk-3 weathers to a buff color and comprises much of the Alfred Creek basin and the low hills dividing the headwaters of Albert and Alfred Creeks. A purple and light-green tuff horizon of this unit often forms the contact between map units Jtk-3 and -4. 'Topographically, unit Jtk-3 occupies the break in slope separating the cliff-forming unit Jtk-1 (below) from the swale-forming unit Jtk-4.

Map unit Jtk-2 is a fine-grained, mordenite-rich tuff. The tuff weathers to tannish white and in some localities has the appearance of porcellanite. Wood fragments and casts can be found in some exposures of this unit on Albert Creek. Often, thin rosettes of radiating mordenite crystals, $1 / 2$ to $1 \mathrm{~cm}$ in diameter, are present in the tuff partings. These crystals are excellent lield guides in locating and mapping this unit. The tuff, which supports little or no vegetation, forms an easily visible white cap on the rounded hills at the head of Albert Creek. In outcrop, the tuff consists of llat or partly conchoidal fragments about $5 \mathrm{~cm}$ in diameter. Unit Jtk-2 appears to be discontinuously distributed within map unit Jtk-3. Careful search revealed no exposures of this unit north. east of the Albert Creek exposures. However, the unit may extend to the southwest side of Alfred Creek, where sample localities 79 and 83 may be part of it. More detailed mapping is needed here.

Map unit Jtk-1 consists mostly of volcanic sandstones and basalt and andesite flows. Tuffs are present but are not as abundant as in other units. Unit Jik-1 forms the cliffs and the summits of the mountains at the head of Alfred and Albert Creeks. The unit is extensively zeolitized, and contains abundant veins of chalky-white laumontite and large 2- to $3-\mathrm{cm}$ vug fillings of pink heulandite. At the head of Alfred Creek basin is a 25-foot-thick layer of mordenite-rich tuff; although mapped as belonging to unit Jtk-1, this tuff has been designated Jtk-2 (o) draw attention to its mordenite enrichment.

Zeolite zonation (discussed on p. 6) indicates that unit Jtk-1 was the most deeply buried unit and is stratigraphically the lowest unit of those mapped. Unit Jtk-5 is considered to be the uppermost unit. This inference is supported by the general 20-degree southe'asterly dip of the lithologic units mapped.

Finally, the contact between the Talkeetna formation units mapped here and the Tuxedni formation mapped by Grantz (1965) was not determined in the present study. Consequently, the area in plate 2 between the northeasterly limits of this study and the l'uxedni formation contact of Grantz has been left blank.

\section{LABORATORY STUDIES}

\section{X-RAY DIFFR ACTION}

X-ray diffraction patterns of the samples were obtained using the procedure previously described (Hawkins, 1973). Samples containing zeolites of the heulandite-clinoptilolite group were heated following the method given by Alietti (1972). This was done to distinguish between heulandite and clinoptilolite and to obtain information on the chemical composition of the heulandite, inasmuch as its thermal stability varies with its chemical composition (Alietti, 1972). Heulandite and mordenite together are difficult to detect by means of X-ray diffraction because they share many peaks. Although it was not used in this study, the technique described by Sudo and others (1963), which relies on the selective dissolution of heulandite (clinoptilolite) in $6 \mathrm{~N}$ HCl, may be useful in subsequent studies. Samples containing $10 \mathrm{~A}$ clay minerals were treated with ethylene glycol and X-rayed again to determine the presence of 
expanding-layer clay minerals. The results of these studies are shown in table 1.

\section{FIELD TEST FOR TEOLITES}

Culfaz and others (1973) proposed a simple field test for zeolites based upon the enthalpy of hydration of dehydrated zeolites. Dehydrated zeolites react exothermally when hydrated and exhibit a rapid and pronounced temperature increase. The amount of the temperature increase depends on the type and quantity of the zeolite present. This test was carried out under laboratory conditions using a muftle furnace in which 5-g samples of powdered zeolitized tuff contained in $35-\mathrm{mm}$ film canisters were heated for 1 hour. The samples were capped and cooled to room temperature. Ten milliliters of water at room temperature were then added to a sample and the slurry was rapidly stirred with a laboratory thermometer. The temperature of the sample before the addition of the water and the maximum temperature of the hydrated sample were observed, and $\Delta \mathrm{T}$, the difference between these two temperatures, was recorded. This process was repeated for each sample. The results of this test are shown in table 1. (Compare with Hawkins, 1973, table 3.)

\section{DISCUSSION}

\section{DISTRIBUTION AND GENESIS ()F ZEOLITTS IN ALFREI) (REEK-ALBERT CREEK AREA}

As shown in Table 1, most of the samples colleeted were zeolite-bearing; mordenite and heulandite were the most abundant zeolites, and laumontite and analcime were the least abundant.

Feolite occurrences for localitie's shown in plate? are especially interesting. The type of zeolite (determined by X-ray diffraction) occurring at a given locality was plotued on a sample-focality map. From this plot it was seen that heulandite oceurred in two zones, mordenite in one zone, laumontite in another zone, and analcime in two localities within the mordenite zone. The zeolite zones are delineated by boundary curves called reolite isograds (pl. 2). Another zone designated in plate 2 as the quart\% zone is tentatively suggested. This zoner?) is based on two samples in which zeolites were absent and quartz had lilled the fractures and cemented the grains.

The position of the laumontite zone is not well established. Only between sample localities 38 and 39 (pl. 2) is the boundary well known. Nevertheless, that a laumontite zone exists is based on this location, on the abundant laumontite float encountered at the head of Alfred Creek, and on the absence of the association laumontite-mordenite. The evidence supports the existence of a laumontite zone that is apparently separated from the mordenite zone by a heulandite zone.

The author examined-..by thermal stability-..here landite from both the heulandite and mordenite zones to see if the polymorphism of the heulandite could be used as a basis of comparison. The heulandite exhibited similar polymorphism, being transformed to Heulandite13 when heated lor 18 hours at $450^{\circ} \mathrm{C}$; in some cases, samples from both zones showed the intermediate phase Heulandite-1, discussed by Alietti (1972). (On the basis of this test, it is concluded that no gross compositional differences exist between the heulandites from the two zones.

The zone's distinguished here correspond to those observed else where throughout the world and constitute the zeolite facies (Seki, 1969; Coombs, 1970). Figure 1 shows possible pressure (P) vs temperature ('T) fields under which the various assemblages are stable. As shown by \%en (1961) and briefly discussed previously by Hawkins (1973), the chemical potential of water in the system is perhaps the most critical variable affecting zeolite stability relations. The more hydrous zeolites mordenite $\left(\mathrm{CaA} \mathrm{I}_{2} \mathrm{Si}{ }_{10} \mathrm{O}_{24} .7 \mathrm{H}_{2} \mathrm{O}\right)$ and heulandite $\left(\mathrm{CaAl}_{2} \mathrm{Si}_{7} \mathrm{O}_{1} \times \cdot \mathrm{HH}_{2} \mathrm{O}\right)$ are stable under a high chemical potential of water, whereas the less hydrous zeolite laumontite $\left(\mathrm{CaAl}_{2} \mathrm{Si}_{4} \mathrm{O}_{12} \cdot 4 \mathrm{H}_{2} \mathrm{O}\right)$ is less stable under these conditions, The erhemicat potential of water in the system varies with the partial pressure of water and salinity. Increasing salinity of intrastratal waters at depth has the same effect as increasing temperature in promoting a zonation from more hydrous to less hydrous phase's.

The activity of siliea in the system is another important variable. In going from mordenite through heulandite to laumontite there is a progressive desilication. Possibte reactions for calcium end-member zeolites are:

$$
\begin{aligned}
& \text { Calcium Mordenite } \rightarrow \text { Heulandite } \\
& \left.\mathrm{CaAl}_{2} \cdot \mathrm{Si}_{10} \mathrm{O}_{2}, 4 \cdot 7 \mathrm{H}_{2} \mathrm{O}\right) \overrightarrow{\mathrm{Ca} \mathrm{Al}_{2}} \mathrm{Si}_{7} \mathrm{O}_{18} \cdot 6 \mathrm{H}_{2} \mathrm{O} \\
& \begin{array}{l}
\text { Quartz } \\
+3 \mathrm{SiO}, 2
\end{array}+\mathrm{H}_{2} \mathrm{O}
\end{aligned}
$$

$$
\begin{aligned}
& \text { Heulandite } \rightarrow \text { Laumontite }
\end{aligned}
$$

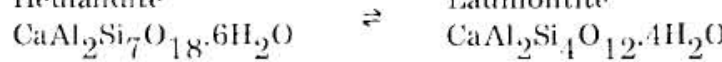

$$
\begin{aligned}
& \text { Quart\% + Water } \\
& 3 \mathrm{Si}()_{2}+2 \mathrm{H}_{2}()
\end{aligned}
$$

Other reactions are possible and have been extensively studied by Seki (1969, 1972, 1973).

Reaction 2, or a variant involving plagioclase, seems to have occurred in the area studied, inasmuch as samples 76 and 36 , both apparently similar lapilli tuffs, have been altered to heulandite and quartz-laumontitecalcite, respectively,

As reaction 1 shows, the formation of mordenite requires a higher activity of silica than does heulandite. The position occupied by mordenite in the zeolite facies is presently a subject of debate. Utada (1970, 1971), for example, shows that mordenite occupies 
TABLE 1. Sample, hand-specimen description, and mineralogy as determined by Xray diffraction and results of field test

\begin{tabular}{|c|c|c|c|}
\hline Sample & 1)escription & Mincralogy & $\begin{array}{c}\Delta \mathrm{T} \\
\left({ }^{\circ} \mathrm{C}\right)\end{array}$ \\
\hline 1 & Tuffaceous wacke & Quartz, feldspar, heulandite & 2.0 \\
\hline 2 & Tufi & Quartz, feldspar, chlorite, mordenite & 6.5 \\
\hline 3 & Tuffaceous wacke & Quartz, feldspar, chlorite, heulandite & 3.0 \\
\hline 4 & Tuffaceous wacke & Quartz, feldspar, heulandite & 1.0 \\
\hline 5 & Volcanic arenite & Quartz, leldspar, chlorite, heulandite & 2.1 \\
\hline 6 & Siltstone & Quart $\%$ montmorillonite & .. \\
\hline 7 & Basalt & Feldspar & $\cdots$ \\
\hline 8 & Pumiceous tuff & Quart $\%$ feldspar, heulandite & 6.5 \\
\hline 9 & Basalt & Feldspar, montmorillonite &.. \\
\hline 10 & Dacite(?) & Quartz, feldspar & -. \\
\hline 11 & Basalt, altered & Quartz, feldspar, mordenite & 0.4 \\
\hline 12 & Tuffaceous wacke & Feldspar, chlorite & -. \\
\hline 13 & Basalt & Quartz, feldspar, montmorillonite & -. \\
\hline 14 & Vitric tulf & Quartz, feldspar, heulandite & 4.0 \\
\hline 15 & Andesibe & Feldspar, chlorite & .. \\
\hline 16 & 'Tuffaceous wacke & Quartz, feldspar, heulandite & 4.6 \\
\hline $17 \mathrm{a}$ & Vitric tufl & Quartz, feldspar, heulandite & 4.6 \\
\hline $17 \mathrm{~b}$ & Vitric tuff & Quartz, feldspar, mordenite & 4.6 \\
\hline 18 & Vitric tuff & Quartz, feldspar, mordenite & 8.0 \\
\hline 19 & Tuffaceous wacke & Quartz, leldspar & .. \\
\hline 20 & Tulfaceous wacke & Quartz, feldspar, heulandite & 5.8 \\
\hline 21 & Tuffaceous wacke & Calcite, analcime & 1.0 \\
\hline 22 & Tuff & Quartz, feldspar, mordenite & 6.2 \\
\hline 23 & Tuffaceous wacke & Quartz, feldspar, heulandite & 1.5 \\
\hline 24 & Tuff & Quartz, feldspar, heulandite & 3.0 \\
\hline 25 & Lapilli tuff & Quartz, feldspar, heulandite & 3.9 \\
\hline 26 & Tuffaceous wacke & Quartz, feldspar, heulandite & 4.0 \\
\hline 27 & Tuff & Quartz, feldspar, mordenite & 5.3 \\
\hline $28 \mathrm{a}$ & Vein filling & Calcite, heulandite & 2.4 \\
\hline $28 \mathrm{~b}$ & Vitric tufi & Quartz, feldspar, mordenite & 1.0 \\
\hline 29 & Tuflaceous wacke & Quartz, feldspar, montmorillonite & .. \\
\hline 30a & Tuffaceous wacke & Quartz, feldspar, heulandite & -. \\
\hline $30 \mathrm{~b}$ & Quartz-heulandite vein & Quartz, heulandite & .. \\
\hline 31 & Tulf & Quart\%, feldspar & .. \\
\hline 32 & Vitric tuft & Quartz, feldspar, heulandite & 2.4 \\
\hline 33 & Vesicular basalt & Feldspar, montmorillonite & -. \\
\hline $34 a$ & Tulfaceous wacke & Quartz, feldspar, heulandite & 3.1 \\
\hline $34 \mathrm{~b}$ & Tuflaceous wacke & Quartz, feldspar, chlorite & - \\
\hline $34 \mathrm{c}$ & Tulfaceous wacke & Quart\%, feldspar, heulandite & -. \\
\hline 35 & Tuffaceous wacke & Quartz, feldspar, heulandite & 1.0 \\
\hline 36 & Lapilli tuff & Quartz, calcite, laumontite & 2.2 \\
\hline 37 & 'Tullaceous wacke & Quartz, leldspar, heulandite & .. \\
\hline 38 & Basalt & Feldspar, chlorite, heulandite & .. \\
\hline 39 & Vitric tulf & Quartz, feldspar, mordenite & 12.5 \\
\hline 40 & Tulfaceous wacke & Quart, feldspar, montmorillonite & .. \\
\hline 41 & Lapilli tuft & Quart:, feldspar, mordenite & 2.2 \\
\hline 42 & Tulfaceous wacke & Quartz, feldspar, heulandite & 1.5 \\
\hline 43 & Tulf & Quartz, feldspar, mordenite & 10.5 \\
\hline $44 a$ & Tufi & Quartz, feldspar, mordenite & 10.0 \\
\hline $44 \mathrm{~b}$ & Heulandite vein & Heulandite & 4.2 \\
\hline $44 \mathrm{c}$ & Lapilli tulf & Quartz, feldspar, mordenite & -. \\
\hline 45 & Tuff & Quartz, foldspar, mordenite & 7.2 \\
\hline 46 & Lapilli tuft & Quartz, heulandite & 6.4 \\
\hline 47 & Lapilli tuff with heulandite, float & Quartz, feldspar, heulandite & -. \\
\hline 48 & Lapilli tufi & Quartz, feldspar, mordenite & 5.6 \\
\hline 49 & Andesite & Feldspar, analcime, montmorillonite & 0.8 \\
\hline
\end{tabular}


TABLE 1,- Continued

\begin{tabular}{|c|c|c|c|}
\hline Sample & Description & Mineralogy & $\begin{array}{l}\Delta \mathrm{T} \\
\left({ }^{\circ} \mathrm{C}\right)\end{array}$ \\
\hline $50 \mathrm{at}$ & Tuff, float & Quartz, feldspar, montmorillonite & .. \\
\hline $50 b$ & Tuif, float & Quartz, feldspar, heulandite & 7.8 \\
\hline 51 & Tulf, float & Quartz, calcite & .. \\
\hline 52 & Tulfaceous wacke & Quartz, feldspar & -. \\
\hline 53 & Tuff & Quartz, feldspar, montmorillonite & -- \\
\hline 54 & Claystone & Quartz, feldspar & - \\
\hline 55 & 'Tulf with zeolite(?) veinlet & Quartz, feldspar, mordenite & - \\
\hline 56 & Tulf & Quartz, heulandite & -. \\
\hline 57 & Tulf & Quartz, feldspar, heulandite & 4.6 \\
\hline 58 & Tulfaceous wacke & Quartz, feldspar, mordenite & .. \\
\hline 59 & 'Tulf & Quartz, feldspar, latumontite & $-\cdot$ \\
\hline $60 \mathrm{a}$ & Folsic tulf & Quartz, feldspar & -- \\
\hline $60 \mathrm{~b}$ & Felsic tuff & Quartz, feldspar & - \\
\hline $61 \mathrm{a}$ & Felsic tuff & Quartz, feldspar & -- \\
\hline $61 \mathrm{~b}$ & Felsic tull & Quartz, feldspar & .. \\
\hline $61 \mathrm{c}$ & Felsic tulf & Quartz, feldspar, muscovite & -- \\
\hline $61 \mathrm{~d}$ & Felsic turf & Quartz, feldspar & -- \\
\hline 62 & Felsic tufl & Quart\%, feldspar, muscovite & .. \\
\hline 63 & Felsic tuli & Gilass & - \\
\hline $64 a$ & Felsic tufl & Quart\%, feldspar, montmorillonite & $-\cdot$ \\
\hline 641 & Vug filling in felsic tuff & Heulandite & -- \\
\hline 65 & Lapilli tufi & Quartz, feldspar, heulandite & 5.0 \\
\hline 66 & Vitric tufl & Quartz, heulandite & 8.5 \\
\hline 67 & Tuffaceous wacke & Quart\%, feldspar, heulandite & 6.0 \\
\hline 68 & 'Tuffaceous wacke & Quartz, feldspar, heulandite & 3.5 \\
\hline 69 & Vitric tufi & Quarte, feldspar, mordenite & 10.3 \\
\hline 70 & Pumice with heulandite & Heulandite & + \\
\hline 71 & Vitric tuff & Quart $\angle$, feldspar, mordenite & 10.3 \\
\hline 72 & Lapilli tuff & Quartz, feldspar, heulandite & 3.7 \\
\hline $73 a$ & Vitric tuff with mordenite erystals & Quartz, feldspar, mordenite & - \\
\hline $73 \mathrm{~b}$ & Vitric tuff & Quartz, feldspar, mordenite & 13.5 \\
\hline $74 a$ & Vesicular basalt, float & Quart\%, leldspar, laumontite & .. \\
\hline $74 \mathrm{~b}$ & 'Tuif, lloat & Quartz, heulandite, montmorillonite & -. \\
\hline $74 \mathrm{c}$ & Tuff, float & Quartz, feldspar, montmorillonite & 7.0 \\
\hline $74 d$ & Tuft, float & Quart $z$, feldspar, laumontite & 1.4 \\
\hline $74 \mathrm{e}$ & Vesicular basalt & Feldspar, montmorillonite & .. \\
\hline 75 & Lapilli tul' & Quartz, feldspar, mordenite & 5.5 \\
\hline 76 & Lapilli tufi & Feldspar, montmorillonite, heulandite & 2.0 \\
\hline 77 & Quartz, opaline silica vein & Quartz & .* \\
\hline 78 & Tuff & Quartz, feldspar & -. \\
\hline 79 & Vitric tulf & Quart:, mordenite & 12.0 \\
\hline 80 & Heulandite vug lilling & Heulandite & $\cdots$ \\
\hline 81 & Tuffaceous wacke & Feldspar, heulanclite & 3.0 \\
\hline 82 & Lapilli tuff & Quart\%, feldspar, montmorillonite, heulandite & 3.0 \\
\hline 83 & Vitric tuff & Quartz, feldspar, mordenite & 11.0 \\
\hline 84 & Tuff, float & Quart $z$, feldspar, heulandite & 7.8 \\
\hline 85 & Tuff, float & Quartz, feldspar, mordenite & 12.0 \\
\hline 86 & Vitric tuff & Quart\%, feldspar, mordenite & 13.0 \\
\hline 87 & Basalt & Feldspar, montmorillonite & -- \\
\hline 88 & Pumice with zeolite(?) lloat & Quartz, leldspar, laumontite & 2.0 \\
\hline $89 a$ & Tuff & Quartz, feldspar, mordenite & -- \\
\hline $89 b$ & Tufl with heulandite veinlet & Quartz, feldspar, heulandite & - \\
\hline $89 c$ & Lapilli tuff & Feldspar, montmorillonite & .. \\
\hline 90 & Heulandite cobble & Heulandite &.$\cdot$ \\
\hline 91 & 'T'uft' & Lost sample & -. \\
\hline $92 \mathrm{a}$ & Vitric tuff & Quartz, feldspar & .. \\
\hline $92 b$ & Tuflaceous wacke & Quart\%, feldspar & $-\cdot$ \\
\hline
\end{tabular}


the lowest P-T region of the zeolite facies (fig. 1), whereas Seki and others (1972) have shown that mordenite can occupy a P-T region extending well into the laumontite zone. Seki observed that mordenite in these cases is confined to fine-grained pumice tuffs, where it was formed by devitrification of glass shards The relatively coarse-grained, more permeable tuff breccias associated with the pumice tuffs were altered to laumontite or prehnite. Apparently the restricted permeability and the greater reactivity of the pumice tuffs permitted the required elevated silica activity to be reached for mordenite formation in rocks that otherwise alter to the laumontite-prehnite assemblage.

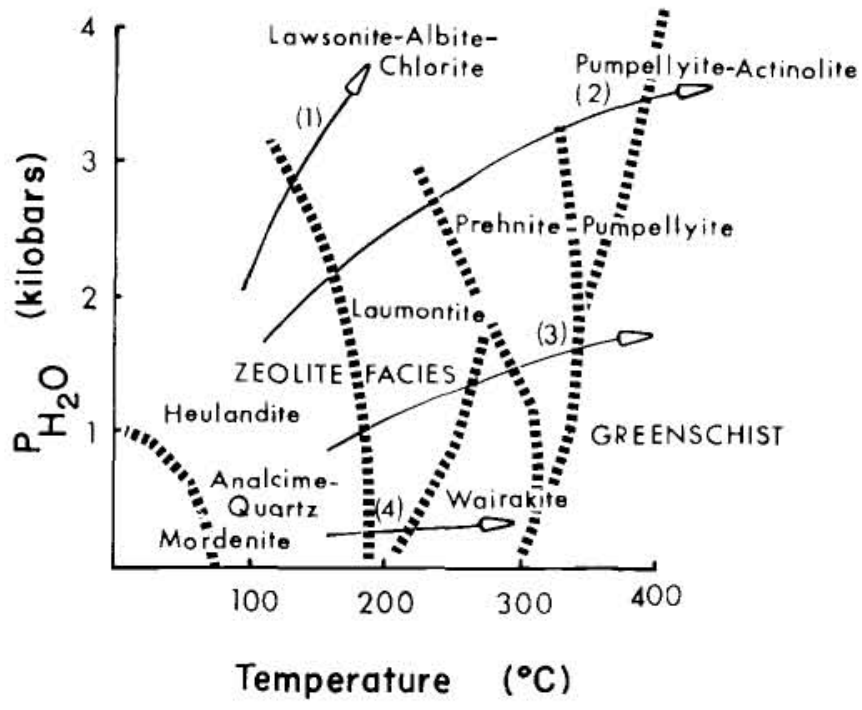

FIGURE 1. Possible pressure-vs-temperature lields lor low-grade mineral facies. Arrows represent facies series as follows: (1) high pressure, low temperature; (2) intermediate; (3) low pressure intermediate; (4) lowest pressure. [Diagram from Coombs (1970). J

With few exceptions, mordenite occurrences are confined to tuffs with heulandite occurring commonly in the coarser-grained tuffaceous wackes (table 1). This observation is also evident from figure 2 , where it is seen that the mordenite zone is more or less confined to map unit Jtk-3, a map unit dominated by tuffs. Petrographically, mordenite is not a common void filler in the coarser lithologies but is confined to pumice fragments. vitric tuffs, and voids within these fine-grained rocks. From these observations, the mordenite occurrence in this area may be similar to that described by Seki (1973: and others, 1972), and the formation of mordenite in this area is controlled mainly by the nature of the reactants and secondarily by the P-T conditions of burial.

Analcime occurrences seem to be localized within the mordenite zone. To date, only one sample (No. 21) has been petrographically studied; hence the conclusions drawn are very tentative. Both calcite and analcime occur in this sample. As is evident from table 1 , calcite is not a common constituent of the rocks studied, and the occurrence of calcite in this rock is very likely associated with the occurrence of analcime. In sample 21, calcite occurs as matrix and as cement for the 'framework' grains of analcime and as pseudomorphs after plagioclase. Where fresh, unaltered-appearing plagioclase $\left(\Lambda n_{45}\right)$ grains are abundant in many other samples, only calcite pseudomorphs remain in the plagioclase in sample 21. In this sample, analcime seems to have formed from pumice fragments but, unlike mordenite or heulandite, which replace the glass shards and preserve the texture of the shards, no shardlike texture remains and the analcime forms aggregates of crystals.

Boles (1972) discussed the formation of analcime from heulandite and clinoptilolite, and pointed out that this mode of formation is favored by alkaline solutions. $\mathrm{He}$ states that in the Murikiku Supergroup, Southland New \%ealand, both clinoptilolite heulandite and analcime occur in altered tuffs-..locally in the same bed. Furthermore, as he discusses marine sediments, the requisite high $\mathrm{pH}$ for analcime formation can be obtained by loss of $\mathrm{CO}_{2}$ from sea water isolated from the atmosphere. An analogous situation may have prevailed for the analcime formation in sample 21. The calciteanalcime assemblage could have formed by the alteration of a mordenite tuff in a locally alkaline environment, which was created by isolation of intrastratal fluids from the atmosphere, loss of $\mathrm{CO}$, to form calcite, and finally the precipitation of analeime. Again, this conelusion is tentative and more detailed chemical and petrographic studies are needed.

The ubiquitous occurrence of quart\% in the samples requires comment. With the few exceptions of samples $92 \mathrm{a}, 92 \mathrm{~b}, 77$, and the quartz-laumontite rocks (sample's 34 and 74), quartz is not readily evident petrographically. The framework grains in the tuffaceous wackes are plagioclase, pumice, and lava fragments. The X-ray diffraction study clearly shows that the pumice fragments and the matrix of these rocks have been altered to zeolites and mierocrystalline quartz. Vitric luffs are similarly altered. The quartz-zeolite association suggests the following generalized reaction:

\section{Andesite(?) Glass + Water ₹ Zeolites + Quart\%}

'The apparent syngenetic association of quartz and the zeolites mordenite and heulandite implies that the activity of silica in the diagenetic system in which the zeolites formed was controlled by the solubility of quartz.

The presence of quartz as vein filling and cement in samples $92 \mathrm{a}$ and $92 \mathrm{~b}$ is striking. This may be a strictly local occurrence of quartz; however, the absence of zeolites and the occurrence of quartz in their stead may suggest the existence of a possible quartz zone (pl. 2). If this zone is valid, it represent the lowest P.'] zone of 
diagenesis and burial metamorphism.

There appear to be two zeolite zones, heulandite and laumontite, indicative of different intensity of metamorphism, and these zones probably formed in response to low-grade metamorphism of volcanic detritus in a eugeosynclinal trough. The mordenite zone represents heulandite subfacies pressure-temperature conditions and its occurrence in this zone is due to the control exerted by the reactants. 'The occurrence of analcime is due to local ehemical conditions existent in the mordenite zone.

Because the position of the heulandite-laumontite boundary depends on the salinity of the system in which metamorphism occurred, the volcanic sediments in the study area could have been subjected to maximum temperatures around $200^{\circ} \mathrm{C}$ and water pressures probably around 0.5 to 3 kilobars. Inereased salinity of the system would lower the temperature of the heulandite-laumontite boundary. Sediments in the heulandite zone were less deeply buried than were those in the laumontite zone. Thus, the depth of burial of the rocks studied appears to increase from the southeast to the northwest as mentioned earlier. However, zeolite zonation may result from variations in chemical com. position of the fluids independent of burial depth. The mechanism resulting in the observed zeolite zonation cannot be established unequivocally at this time. For example, the mordenite zone may represent the lowest grade zeolite assemblage. As shown in plate 2, this requires that the metamoiphic grade increase in both a southeastorly and a northwesterly direction from the mordente zone. This could oceur if the mordenite-zone sediments oecupied the crest of an anticline and the heulandite-zone sediments occupied the flanks of this anticline during diagenesis. Then, as a result of deeper burial, the flank sediments were increased in metamorphic grade. Structural-geologic evidence at present is inadequate to either support or refute this hypothesis.

\section{O'THER LOCALITHES STUDHED}

Plate 1 shows the foration from which samples were taken to investigate possible zeolite localities in other parts of the Horn Mountains - Caribou Creek area. Zeolites are present in samples (Nos. 50-58) more or less confined to the previously mentioned segment (p. 2) of the Talkeetna formation. This area should be investigated further to determine if zeolite deposits of possible economic value are present.

The lack of zeolites in samples from localities 60-64 was disappointing. These samples are from a thick, wellexposed sequence of Tertiary felsic tuffis at the headwaters of Caribou Creek. Except for a few zeolites in vugs in vesicular lavas associated with the tuffs, no zeolites were found in this area. Zeolitization of local beds within the tuft sequence may be present, but large-scale zeolitization of the type shown by the Talkeetna formation does not seem to be present. A more careful examination of these tuffs should be carried out; however, yet-uninvestigated exposures of the Talkeetna formation in the general area should be studied lirst.

\section{ECONOMIC PO'TENTIAL OF MORDENITE DEPOSITS}

The mordenite-rich tuffs designated Jtk-2 are of potential economic value. The areal extent and thick. ness of these tuffs are shown in plate 2. The extent of the mordenite-tuff horizon in the upper heulandite zone at the head of Alfred Creek remains to be determined. This horizon is certainly more extensive than is shown in the plate: however, time did not permit the horizon to be traced further.

An estimate of the grade of the mordenite tuffs can be made from the results of the zeolite field test (table 1). The samples shown in table 2 (excerpted from table 1) are from unit Jtk-2. The mordenite-rich samples 79 and 83 may also be from this unit, but more detailed mapping is needed to establish this.

Assuming that a pure mordenite sample would show a $\Delta T^{\prime}$ value of $16.3^{\circ} \mathrm{C}$ and that $\Delta \mathrm{T}$ increases linearly with increasing concentration of mordenite, the mean and standard deviation values of $\Delta \mathrm{T}$ of $10.8^{\circ}$ and $2.34^{\circ}$ correspond to an average mordenite concentration of 66 percent, which varies from 38 to 95 percent for two standard deviations about the mean value. In other words, 95 pereent of the time, the mean value of the mordenite concentration can be expected to fall between 38 to 95 percent. The mean grade is similar to that of the Union Pass, Mohave County, Arizona depesit and the Malheur County. Oregon deposit mined

TABLE 2. Kesults of zeolite field test for mordenile-rich samples

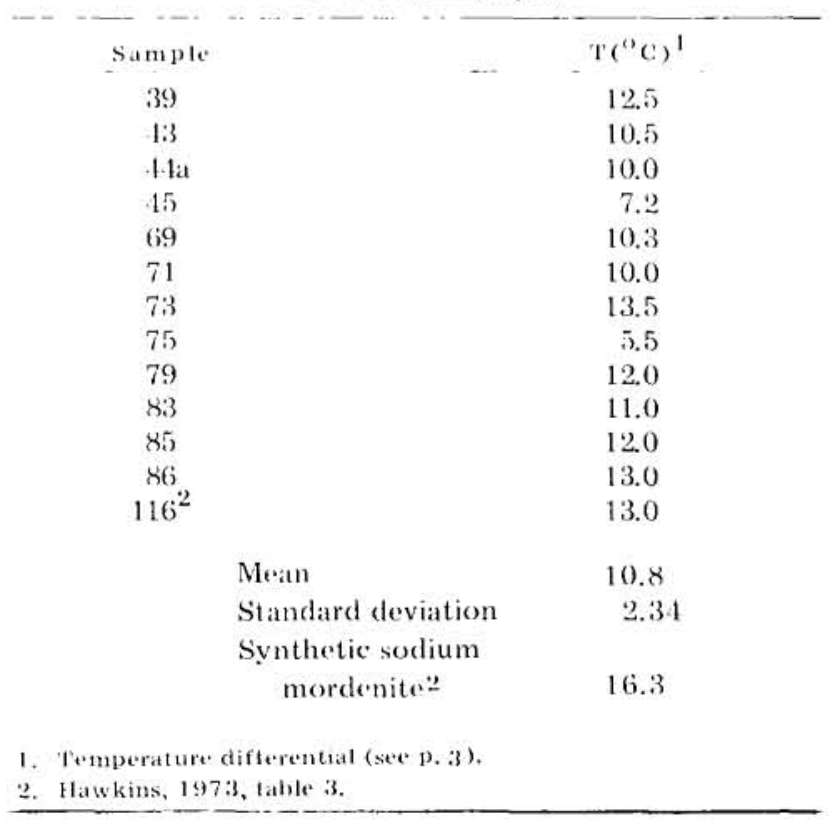


by Union Carbide and Norton, respectively (Mumpton, 1973). There are several patented processes (Hawkins, 1973, Appendix 1) for the beneficiation of zeolite ores. In addition, Norton has developed a leaching process that yields a zeolite product with adsorption properties similar to those of synthetic mordenite (Sand, 1968). ( $\Lambda \mathrm{n}$ idea of the properties of the mordenite deposit studied here ean be obtained from the data shown in table 3 of Hawkins. 1973.) In addition, a rapid method for the evaluation of adsorptive properties of zeolites has been developed by Landolt (1971).

The mordenite deposit studied here is of commercial grade and extent, and further study of the properties of the mordenite should be carried out. The manner in which the mordenite might be used in Alask a remains to be determined. Applications involving large quantities of zeolites where uniformity of the properties of the zeolite is not critical should be sought. Synthetic zeolites, which have uniform properties foften for a particular application), are not likely to be directly economically competitive.

'The horticultural usefulness of laumontite tuffs from Sheep Mountain (Hawkins, 1973) was tested by D.H. Dinkel of the University of Alaska, $\Lambda$ gricultural Experiment Station. The details of this test are not available at this time, but Dinkel (personal communication, 1974) concluded that the laumontite tuffs had no noticeable effect in hydroponic experiments involving the growth of cucumbers. It may be that the laumontite tufts are indeed valueless in agricultural applications or that some form of pretreatment of the tuff is necessary to render it agriculturally useful. More work remains to be done here, even though the results of initial experiments are disappointing.

\section{FIELD TLEST FOR ZEOLITES}

The field test for zeolites published by Culfaz and others (1973) gave results in good agreement with those obtained by X-ray diffraction. The test seems to be much less subject to interference by clay minerals than is the test of Helfferich (1964), which was evaluated by Hawkins (1973). The test was not evaluated under field conditions. The greatest utility of the test may lie in complementing the X-ray data and quickly estimating zeolite grade in monozeolitic tuffs. The test should find considerable use.

\section{CONCLUSIONS}

The mordenite-rich tuffs investigated in this study are of commercial grade. The properties of the mordenite should be investigated further to determine if it meets current industrial requirements. Mordenite deposits in other parts of the Talkeetna formation in the general study area should be sought.

The zeolites in the area were formed by burial diagenesis and regional metamorphism of volcanic detritus deposited in a eugeosynclinal trough. The existence of heulandite and laumontite zones indicates a difference in metamorphic grade of the rocks in the area, with heulandite being the lower grade mineral and laumontite the higher grade mineral. This difference in grade may be due to the difference in depth of burial, that is, the volcanic sediments of Horn Mountains and those at the head of $\Lambda$ lbert Creek were more deeply buried than were those at the mouth of Albert Creek and North Creek. The sediments were subjected to maximum temperatures around $200^{\circ} \mathrm{C}$ and water pressures around 0.5 to 3 kilobars, which corresponds to burial depths of 1 to 10 kilometers. The temperature of the heulandite-laumontite boundary was probably less than $200^{\circ} \mathrm{C}$ because of the effect of salinity of the intrastratal waters on the activity of water during metamorphism.

Mordenite occurred within the heulandite zone because of the fine-grained nature of the tuffs, causing a higher silica activity in the intrastratal fluids than in the rest of the zone. Analeime may have formed locally from a mordenite or heulandite tuff by solutions locally more alkaline than those throughout the mordenite zone.

The field test of Culfaz and others (1973) gives reliable results and should be used.

\section{REFERENCES}

Alietti, A., 1972, Polymorphism and crystal chemistry of heulandites and clinoptilolites: Am. Min. 57, p. $1448-1462$.

Boles, J.R., 1971, Synthesis of analcime from natural heulandite and clinoptilolite: Am. Min. 56, p. 17241734.

Coombs, D.S., 1970, Present status of the zeolite facies, in Preprints of the Sec. Int'l. Conf. on Molecular sieve zeolites: Worcester Polytechnic Institute, p. $556-566$.

Culfaz, A., Kiesling, C.H., and Sand, L.B., 1973, A field test for molecular sieve zeolites: Am. Min. 58, p. 1044-1048.

Grantz, A.M., 1965, Geologic map and cross sections of the Nelchina area, south-central Alaska: U.S. Geol. Survey open-file report.

Ilawkins, D.B., 1973, Sedimentary zeolite deposits of the upper Matanuska Valley, Alaska: Alaska Div. Geol. and Geophys. Surveys, Spec. Rpt. 6.

Helfferich, F., 1964, A simple identification reaction for zeolites (molecular sieves): Am. Min. 49, p. 1753 1754.

Landolt, G.K., 1971, Method of rapid determination of adsorption properties of molecular sieves: Anal. Chem. 43 (4), p. 613-615.

Mumpton, F.A., 1973, Worldwide deposits and utilization of natural zeolites: Industrial Minerals 73, 
October, p. 2-11.

Mlunson, R.A., and Sheppard, R.A., 197. Natural zeolites - their properties, occurrences and uses: Hin. Sci. Engng $6(1)$, p. 19)-31.

Sand, L.B., 1968, Synthesis of large-pore and smallpore mordenites, in Molecular sieves: soce. ('hem. Ind.. p. 71.77 .

Seki, Y., 1969, Facies series in low-grade metamorphism: J. (ieol. Soc, Japan, 75 (5), p. 255-26ti.

1973. Ionic substitution and the stability of mordenite: J. Cieol. Soc. dapan, 79(10). p. 669-676.

Seki, Y., Oki, Y.. Odaka, S.. and Ozana K., 1972. Stability of mordenite in zeolite facies metamorphism of the Oyama-[sehara district, east l'anzawa Iloun- tains, central dapan: J. (ieol. Soe Japan, 78 (3), p. $115-160$.

Sudo, T., Nisgama. T., ('hin. K., and Hayashi H., 1963, Mordenite and elinoptilolite in glassy tults of Japan: J. (ieol. Soce dapan, 69, p. 1-11.

litada, M., 1970, 1)ecurrence and distribution of authipenic zeolite's in the Neogene pyroclastic rocks in Japan: Sci. Paper coll. Gen. Lidue., Univ. Tokyo, 20, p. $191 \cdot 263$.

1971. Note on the zeolitic zoning of the Neogene proctastic roetis of dapan: Mem. (ivol. Soce Japan. 6. p. $195-200$.

Zen, E-an, 1961, The zeolite facies; an interpretation: Am. J. Sci., 259, p. 401.409. 